\title{
The Mountain Is High, and the Emperor Is Far Away: States and Smuggling Networks at the Sino-Vietnamese Border
}

\author{
Qingfei Yin
}

The intense and volatile relations between China and Vietnam in the dyadic world of the Cold War have drawn scholarly attention to the strategic concerns of Beijing and Hanoi. In this article I move the level of analysis down to the border space where the peoples of the two countries meet on a daily basis. I examine the tug-of-war between the states and smuggling networks on the Sino-Vietnamese border during the second half of the twentieth century and its implications for the present-day bilateral relationship. I highlight that the existence of the historically nonstate space was a security concern for modernizing states in Asia during and after the Cold War, which is an understudied aspect of China's relations with Vietnam and with its Asian neighbors more broadly. The border issue between China and its Asian neighbors concerned not only territorial disputes and demarcation but also the establishment of state authority in marginal societies. Keywords: smuggler, antismuggling, border, Sino-Vietnamese relations, tax.

Historically, the Chinese empire and, to a lesser extent, the Dai Nam empire that followed the Chinese bureaucratic model had heavyweight states with scholar-officials chosen by examination in the Confucian classics (Woodside 1971). However, as the proverb goes, the mountain is high, and the emperor is far away. Vast distances and weak connections existed between the central government and ordinary people. Central authorities thus had little influence over local affairs, including their own street-level bureaucracies. Continuous wars in the twentieth century, especially the Cold War, had strengthened states, increased their scope and cohesion, and brought governments closer to the people (Westad 2012). Despite the 
unprecedented reach of the state in China and Vietnam as a result of communist state building during the Cold War, political authority in both societies was challenged in areas where government institutions were weak and on issues in which the state representatives lacked expertise. Smuggling at the Sino-Vietnamese border is a vivid example of how spontaneous connections between the Chinese and Vietnamese people survived the fluctuating bilateral relationship between the two countries due to the limited strength of the two states at the border.

In November 2017, China and Vietnam launched their most recent joint antismuggling campaign run by customs agents from southern China's Guangxi Zhuang Autonomous Region and the northeastern Vietnamese provinces of Quảng Ninh, Lạng Sơn, and Cao Bằng (Xinhua Net 2017). Surprisingly, one of the most profitable items smuggled from Vietnam to China is frozen meat, mainly beef. With a burgeoning middle class, demand for high-end meat, such as Japanese Wagyu beef, surged in China. However, the Chinese government banned imports of beef from Japan and some other major meat-exporting countries, citing concerns over mad cow disease. Domestic buyers and international traders thus collaborated in smuggling meat into China through the Sino-Vietnamese border. According to estimates, about one-fourth of the beef consumed in China is illegally imported through Vietnam from Japan, Brazil, and India (Nanfang zhoumo 2014). Officials ascribe rising smuggling and human trafficking at the SinoVietnamese border to "unbalanced economic development and loopholes in social management" after market-oriented reforms in both countries (China Daily 2017). However, traders and smugglers engaged in the underground economy at the Sino-Vietnamese border have long evaded and challenged state authorities in the area.

I examine the tug-of-war between the states and smuggling networks at the SinoVietnamese border during the second half of the twentieth century and its implications for the 
present-day bilateral relationship between the two countries. I argue that, despite the intense and volatile diplomatic relations between Beijing and Hanoi and the radical socialist reforms in both countries during the Cold War, the two communist states never gathered the strength to curb shady activities at the border. Smuggling networks survived not only the socialist campaigns against them but also the continuous Indochina conflicts, including the decade-long SinoVietnamese confrontation on the border after 1979. The current Sino-Vietnamese border is no longer the front line of Cold War confrontation but has become a bridgehead of China's engagement with Southeast Asia. Yet, the struggle continues between political authorities who aim at extracting revenues from the border economy and smugglers who strive to evade the state.

Historians have long debated the sources of the conflicts and conditions of peace between China and Vietnam in the twentieth century (Chen 1969; Guo 1992; Nguyen 2012; Zhai 2000). Ironically, the underground economy was one of the most stable aspects of the bilateral relationship, mostly because of state weakness at the border (Lary 2007; Scott 2009), which made it difficult for officials to restrain existing cross-border connections. I argue that the overall stability of Sino-Vietnamese relations has less to do with overlapping national interests than the thick "international relationships," to use Brantly Womack's term, that developed in spaces where the state authority was fragile and challenged (Womack 2000, 981). The border people managed to maintain the cross-border international relationship when the two socialist neighbors cordially cooperated in antismuggling campaigns and when Beijing and Hanoi headed to confrontation. These international relationships, therefore, were less vulnerable to conflicting national interests.

Besides highlighting an understudied aspect of Sino-Vietnamese relations, this article is also a contribution to the historiography on smuggling and the "second economy" (Grossman 
1977, 25) in the Soviet bloc. Both political motives and economic needs drove the smuggling of contraband goods to the socialist world. Transnational cooperation in Bible smuggling to the Soviet Union, for example, was part of Western anticommunist endeavors during the Cold War (Boel 2014). Within socialist countries, smuggling, bartering, hoarding, speculating, and other forms of the hidden economy supplemented the command economy, often with the acquiescence of local state administrations (Bren and Neuburger 2012; Chan and Unger 1982). In coastal China more specifically, smuggling was a "creative accommodation" employed by various social actors to cope with the transformation toward a planned economy. During the early People's Republic of China, "the nascent command economy and the vibrant underground economy existed symbiotically rather than antagonistically" (Thai 2017, 1561). While scholars have paid much attention to flows of contraband from Western countries to the communist bloc, smuggling and other dimensions of the underground economy across socialist borders have drawn little attention. By examining smuggling within the socialist world, I highlight the shadow economy as a powerful transnational force that has constantly challenged the all-encompassing state.

I begin with a discussion of the political, economic, and geographical conditions that gave rise to the smuggling networks at the Sino-Vietnamese border before the second half of the twentieth century. I then examine how the Chinese and Vietnamese communists dealt with illicit trade between their two countries after they assumed power, followed by an analysis of how the Vietnam War and the Sino-Vietnamese War triggered more smuggling at the border. I conclude with a brief discussion of the bustling contraband business in the area after the normalization of Sino-Vietnamese relations in the 1990s.

\section{A Smugglers' Paradise}


During the first half of the twentieth century, the Sino-Vietnamese border was an adventurers' paradise with bustling smuggling activities, something that greatly concerned the modernizing states of China and French Indochina. The local people had long developed an interdependency in their livelihoods by trading daily necessities such as rice and water buffalo across the border (Turner, Bonnin, and Michaud 2015). After the mid-nineteenth century, expanding European influence in Asia created new economic opportunities at the SinoVietnamese border. Having access to French Indochina by sea, river, and land, the area was on the trade route between southern China and British Hong Kong, Japan, and even the United States. Its financial connections with Canton and Hong Kong were also favorable for commercial activities (Lary 2007).

Burgeoning local and long-distance trade took place simultaneously with the rationalization of the Chinese and French Indochinese states as they demarcated their international boundary after the Sino-French War (1884-1885) and enforced it with military deployment (Notice 1900). As Eric Tagliacozzo argues, "boundary production" and the "boundary transgression (through contrabanding) that accompanied it" are two sides of the same coin. The state expands the definition of illicit goods or narrows it based on self-interest (Tagliacozzo 2005, 3-5). The French colonial regime perceived fake banknotes, illicit drug trades, and human trafficking as threats to state revenues and French prestige (Grémont 2017; Lessard 2015). Nationalist China, meanwhile, launched a "war on smuggling" after the recovery of tariff control (1928-1934). Increased customs duties and coercive measures, ironically, triggered more rampant smuggling (Thai 2016, 82-83).

World War II further left the antismuggling campaigns of the Chinese and French Indochinese states in ruins. By October 1938, all major Chinese coastal ports had fallen to the 
Japanese troops. French Indochina, therefore, became China's only access to Western supplies. In July 1940, however, the French colonial government of Indochina headed by newly appointed Governor-General Jean Decoux closed the border with China under Japanese pressure (Decoux 1949, 69-72). China's war efforts against Japan called for stronger commercial connections across the Sino-Vietnamese border, while the border shutdown handicapped trade to the extent that only smuggling and illegal trade could meet economic demands. This contradiction gave rise to wartime prosperity on the Sino-Vietnamese border.

Dongxing, a town located in southern Guangxi at the intersection of China's land border with Vietnam and its coastline, became a flourishing trade and smuggling hub known as Little Hong Kong during World War II. Bordering Vietnam's Móng Cái across the Ka Long River (also named the Beilun River), the port had direct sea and land access to French Indochina. Then under the administration of the more outward-looking Guangdong province, Dongxing was economically integrated with Indochina, which was much wealthier than the rather isolated southwestern China. A contemporary Chinese traveler, while lamenting the devaluation of the Chinese yuan against Indochinese piasters as a result of an influx of Vietnamese products, commented that "the prosperity of Dongxing was inseparable from imports from Vietnam, without which Dongxing would be a dead city." Active collaboration developed between sellers, buyers, and cross-border transporters. The transporters first paid a security deposit to the sellers after loading the goods. After successful delivery of the cargo to the buyers over land or coastal routes, the smugglers charged about 30 percent commission fees. With personal connections, bribery, and indigenous knowledge of weather and tides, smugglers managed to ship everyday consumer goods and high-value industrial products across the Gulf of Tonkin under the gaze of both French customs inspection boats and Japanese warships. This illicit trade was so profitable 
that the smugglers were able to break even with only one-third of the cargoes delivered (Chen 1944, 61-64). Smugglers of more lucrative contraband goods such as drugs, tungsten ore, tin, and antimony were equipped with arms that often dwarfed the weapons of military patrols and the inspection institutions of the states (GXZG 1941, no. 1241; HGZK 1949, no. 2).

Therefore, when the Chinese and Vietnamese communist states tried to impose priorities and extract revenue from the border after seizing power, they encountered a cosmopolitan society with a porous international boundary, a prosperous trade network, and a fluid population. After Chinese communist forces arrived at China's southern border with Vietnam at the end of 1949, they were only able to place simple and crude checkpoints at key border trade hubs. Zhennan Guan (the present-day Friendship Pass), for example, was a historical mountain pass between China and Vietnam linking Guangxi and Lạng Sơn. In May 1950, the Ministry of Public Security admitted to the State Council that the "border defense at Zhennan Guan in Guangxi falls short of a unified leadership, border check stations, and specialized anti-smuggling organizations" (GSBN 2006, 373-374).

Before suppressing remnant Nationalists and armed bandits, the Chinese communists were mainly disturbed by the perceived "American, French, or Nationalist spies" who could "take advantage of the weakness of border defense, infiltrate into the interior, and collude with feudal forces," instead of the smugglers who trespassed the border for nonpolitical reasons (GSBN 2006, 373-374). Public security forces of Guangdong province who oversaw the Dongxing-Móng Cái border even instructed their border authorities "to be familiar with and educate the thieves, brokers, mafia members, and smugglers" so that those groups could provide useful information to the newly arrived state representatives. Confiscated contraband items were those that directly challenged the political authorities or generated critical revenues such as 
weapons, drugs, foreign currency, gold, silver, and subversive and obscene publications (GDPA no. 204-1-164-015). Only after the "bandit crushing" campaign reached a reasonable level of success in the second half of 1951 did antismuggling assume greater importance to the Chinese border authority. In September 1951, the Bureau of Border Defense of the Department of Public Security of Guangxi instructed that the border checkpoints should "keep spies and agents from infiltrating to the interior, prevent domestic anti-revolutionaries from escaping, and stop smugglers from destabilizing the national economy" (Zeng 1993, 44).

\section{Communist War on Smuggling}

The victory of the Viet Minh in the Vietnamese border area created opportunities for the two communist states to crush smuggling at their shared border. On the one hand, the two socialist partners could collaborate in cracking down on illicit trade. On the other hand, as both China and Vietnam transitioned to a centralized economy, the two communist states found the smugglers particularly problematic because the cross-border shadow economy was a textbook example of capitalism and a formidable challenge to the socialist planned economy. After a successful border campaign in 1950 that was undertaken with the assistance of Chinese military advisers, the Viet Minh drove French forces out of the Vietnamese border with China except for the coastal trading post of Móng Cái (Zhai 2000). The two sides, therefore, decided to open several traditional border trade markets between China and areas under Viet Minh control for "small-scale border trade." In the summer of 1952, the People's Republic of China and the Democratic Republic of Vietnam (DRV) decided to open nine pairs of border markets, including Zhennan Guan-Đồng Đăng and Hekou-Lào Cai (GDPA no. 204-1-292-166). Besides accommodating the long-existing commercial connections across the border, opening these markets would also allow the two communist states to extract customs duties from cross-border 
economic activity and help their state-run companies to participate in the vibrant, profitable border trade. The two sides imposed a trade license system, set tariff rates, and created a list of permitted goods in the small-scale border exchange.

As the communist states started to distinguish legally traded commodities and contraband goods, the issue of antismuggling gained salience. Because it was in the border people's interest not to have their goods counted, inspected, or taxed by the states, the local administrations often had great difficulty drawing the border population into the state project of small-scale border trade. During the second half of 1952, the Viet Minh dispatched cadres to villages in Cao Bằng and Lang Sơn to conduct propaganda on border-trade policies, especially in terms of the importance of paying taxes, taking the designated routes, and attending officially opened markets. By the end of the year, the Vietnamese communists were increasingly dissatisfied with the border people's lukewarm attitude toward the government-endorsed trade. State representatives sent down to the border villages were required to organize traders to participate in the smallscale border trade. The border residents, however, were particularly discontented with regulations that forbade bringing Vietnamese banknotes to China or taking Chinese currency back to Vietnam. The administrations of Cao Bằng and Lạng Sơn, therefore, worried that tighter regulation would provoke even more smuggling (VNA UHKVB no. 5444).

Besides preventing the loss of critical revenue, the communists worked to stem smuggling because they associated some imported industrial goods with a capitalist way of life and foreign influence. One of these dangerous capitalist goods was the so-called French watch, a French-designed, water-resistant watch manufactured in Vietnam that was popular in coastal China. The Chinese communists labeled these watches the symbol of the "economic control of French imperialism" and capitalist consumerism (Guangxi ribao 1952, 1). In 1951, the Guangxi 
provincial customs house launched a crackdown on smuggled watches from Vietnam. According to the investigation, more than 50,000 watches were illegally imported from Vietnam through Dongxing and other border trading hubs; more than 80 percent of them were resold to private merchants in Shanghai, Beijing, Guangzhou, and other large cities in China. The crackdown campaign mainly targeted the owners of major watch store chains in the cities that were blamed for organizing the smuggling rings (HGZ 2010, 173). By contrast, the Chinese state adopted a rather lenient policy toward smugglers along the border during the First Indochina War. The guards in Dongxing, which bordered then French-occupied Móng Cái, were instructed to "respect the historical practice" of cross-border trade and accommodate the vibrant private commerce in order to "win the hearts of people" (GDPA, no. 302-1-10-93 100). The Chinese state's attitude toward watch smuggling demonstrates that antismuggling in a communist country was a financial issue with government revenue at stake as well as a political problem that symbolized the competition between socialism and capitalism.

After the Geneva Conference of 1954, and especially after the complete French retreat from northern Vietnam, the Chinese and Vietnamese states strengthened their economic collaboration and tried to impose a planned economy along their shared border. Their tariff regulations distinguished between international trade and small-scale border exchanges and allowed more favorable tax rates to the latter (Womack 1994). From the perspective of the local administrations, the smugglers not only evaded tariffs but also threatened the profits of the staterun companies. While the state-owned businesses sought to dominate the market by purchasing at a fixed low price and selling at a higher one, the smugglers often beat the state-run companies by making more competitive trade deals (GZARA, no. X1-8-364). Consequently, the Chinese and Vietnamese administrations decided to exclude private merchants living outside the border 
area from the small-scale border exchange in 1954 and 1957, respectively. They hoped that by cutting the connections between smugglers at the border and private shops in the interior province, the smuggling ring would collapse (GZARA, no. X1-8-364; VNA PTT, no. 7642).

In reaction to the expanding definition of smuggling, the smugglers decided to buy their access to the border market. In April 1957, the Vietnamese Prime Minister's Office ordered the border authorities to take tougher measures to keep "the greedy merchants from the interior provinces who take advantage of the shortage of commodities on the domestic markets" out of the border exchange. Three months after the policy was implemented, to Hanoi's disappointment, more private shopkeepers from Hanoi and Haiphong evaded the restriction and engaged in smuggling contraband items by bribing the businessmen, ordinary people, and cadres within the border area (VNA PTT, no. 7642). As Philip Thai argues in his study of smuggling and antismuggling in communist China, while communist China expanded Nationalist China's war on smuggling by employing new tactics of mobilization, smuggling was actually "a lifeline that alleviated widespread material shortages and supplied the everyday needs of individuals and firms during the tumultuous transition to central planning" $(2017,1561)$. On both sides of the border, smuggling was vital to the livelihood of local society.

To accommodate the everyday needs of border society and avoid alienating the border residents, especially the ethnic minorities, the Guangxi provincial government instructed the border patrol forces and customs houses to adopt a lenient policy toward small-scale smuggling by border villagers in July 1957. If caught by the border police, ordinary villagers who engaged in small-scale smuggling would be "educated, taxed, and released" with their goods. In contrast, habitual smugglers, organized smugglers, and those transporting a large amount of contraband would be fined and their smuggled goods confiscated (HGZ 2010, 183). In the mid-1950s, large- 
scale organized smuggling subsided on China's border as a result of the socialist reform of capitalist industry and commerce, which weakened the business connections between the private shopkeepers in the interior provinces and the smugglers and brokers on the border.

The smuggling networks, however, only declined temporarily as material shortages became particularly acute after the Chinese communists launched the disastrous Great Leap Forward (dayuejin) in 1958. After the state pushed forward mandatory agricultural collectivization in the form of people's communes and enhanced grain procurement, villagers in China's border counties, as elsewhere in the country, found themselves facing shortages of food and living necessities. Because Hanoi did not decide to push its agricultural cooperatization movement (phong trào hợp tác hóa nông nghiệ) into the northern mountainous area until November 1959, villagers on the Chinese side could still obtain food from the only remaining private commerce in the area (NADRV 1959). Organized smugglers also reemerged with the rising need for everyday necessities. According to the investigations of the local Vietnamese government, smugglers from China met with Vietnamese sellers through intermediaries or used secret signals that were known only to themselves to evade state surveillance. Benefiting from a trust-based relationship or kinship between the villagers across the border, smugglers could temporarily store the goods they purchased in Vietnam to avoid encountering the border police during the day. At night, they stealthily transported the contraband goods back to China, either through mountain trails that were only known locally or across the Ka Long River from Móng Cái to Dongxing (Author's personal collection 1958). The widening gap in living standards between China and Vietnam revived the organized smuggling that had created wartime prosperity for the Sino-Vietnamese border region in the 1940s. 
Smuggling often involved state evasion by citizens and corruption on the part of local bureaucracies at the same time. Political elites played a particularly important role in smuggling rings during periods of economic difficulty. In 1958, local Chinese officials in Dongzhong, a mountain pass in Dongxing county of Guangxi, noticed the unsettling phenomenon of increasing smuggling of watches, sugar, and salt from Vietnam. To their disappointment, even militiamen who were supposed to defend the government policy were involved in this shadow economy (Author's personal collection 1958). In Jingxi county, the heads of communes and militia members sought to translate their political power into economic gains by using funds from the rural credit cooperatives (grassroots financial institutions) to smuggle a large number of water buffalo from Vietnam (HGZ 2010, 163).

Realizing that many grassroots cadres, such as the militia and communal police, either had a stake in illegal trade or lacked incentives to crush the organized smuggling activities, the Vietnamese government decided to buy the support of these local cadres. In December 1962, the Ministry of Finance stipulated the compensation of the militia, rangers, and commune police responsible for antismuggling campaigns to enhance their morale and "to mobilize various forces in the society to participate in the implementation of tax policy." In June 1964, the Vietnamese government expanded the remuneration from military and police units to "people who help the financial agency to execute tax policy and detect smuggling cases" (Ministry of Finance 1964). Hanoi's measures highlighted the limited coercive strength of the communist state in suppressing smuggling. Trading contraband was such a lucrative business as well as an economic necessity in border society that the state had to offer material incentives to help keep its bureaucracy rational and disciplined.

\section{The Indochina Wars and Smuggling Tides}


During the Vietnam War, as the Cultural Revolution and Hanoi's war efforts against USbacked South Vietnam hindered the two communist states' capabilities to crush smuggling, smugglers at the Sino-Vietnamese border managed to further "navigate fluctuations in state power" (Turner 2010, 268). On the one hand, Vietnamese population relocation to the border area as a result of US bombing resulted in material shortages and an increasing need for crossborder trade. On the other, the Cultural Revolution led to conditions of virtual anarchy on China's border, thus paralyzing the Chinese state's antismuggling institutions. Following a Vietnamese attack on a US airbase near Pleiku in February 1965, the United States launched a series of bombing campaigns against the North Vietnamese military and industrial infrastructure as well as the Ho Chi Minh Trail (Sieg 2002, 430). To reduce damage, the Vietnamese Workers' Party decided to relocate some urban residents to the mountainous areas near the Chinese border. Besides this government-sponsored evacuation, more than 3,000 ethnic Chinese (Hoa kiều) traders in Vietnam moved back to Dongxing in 1965. Yet, they were unable to secure livelihoods within the command economy in China as food and daily necessities were only supplied under a quota system. They had to smuggle spices, pearls, seafood, and watches from Vietnam in exchange for light industrial products and medicines from China for sale in Vietnam (HGZ 2010, $162,173)$.

As the Vietnamese state was unable to supply its citizens who were relocated to the border area with adequate food and daily necessities, its willingness to crush contraband smuggling significantly declined. For wartime Vietnam, the shadow economy relieved the material and food shortages in its border provinces that had been caused by the relocation of its urban population there. At a meeting between the provincial governments of the border provinces of China and Vietnam in March 1965 in response to the escalating war in Indochina, 
the Vietnamese representatives indicated that the two governments should accommodate existing cross-border connections due to the "long-standing affection of the two peoples at the SinoVietnamese border." Lenient border procedures could be adopted especially during Tet, the lunar New Year, so that people could take a generous portion of gifts, food, and daily necessities across the border that were exempt from customs tariffs. Furthermore, they proposed relying on "education" and "persuasion" to reduce water-buffalo smuggling instead of imposing coercive measures (VNA PTT, no. 8104).

As the Vietnamese state gave tacit assent to the shadow economy at the border, political chaos during the Cultural Revolution also put a halt to antismuggling efforts on the Chinese side. In August 1966 China's supreme leader Mao Zedong encouraged the militant student organization the Red Guards and their attack of "capitalist roaders" in government. The nationwide "seizing power" movements further paralyzed bureaucratic institutions (Dikötter 2017, xx-xxii). The Cultural Revolution in Guangxi was particularly violent due to the province's remoteness and armed factional conflicts (Sutton 1995). Affected by a radical leftist line, China's border authorities shifted the priorities in their agenda from enforcing the international boundary to propagandizing Maoism, devoting more time to holding sessions studying Mao's teachings than to activities such as crushing smuggling (Zeng 1993). Customs officers who conducted investigations of the smuggling rings in Guangxi were attacked and killed (HGZ 2010, 173). As armed factional conflicts in Guangxi entered their bloodiest year in 1968, the border customs inspection institutions collapsed and were not restored until 1972. As state strength declined, heightened smuggling and a thriving black market reinvigorated the transnational and interprovincial smuggling rings of opium, gold, and watches that the Chinese and Vietnamese governments had tried so hard to crush in the 1950s (HGZ 2010, 162). 
Even though Sino-Vietnamese relations chilled in mid-1968 as Hanoi and Washington started to negotiate after the DRV launched the Tet Offensive, smuggling networks continued to prosper at the border (Zhai 2000). In 1970, a daily average of 400 to 500 people crossed the Ka Long River between Dongxing and Móng Cái without completing any border crossing procedures under the gaze of a paralyzed state apparatus (Author's personal collection 1973). After 1974, an increasing number of itinerant merchants including ethnic Chinese traders in Vietnam and ethnic Vietnamese in China engaged in smuggling along the border (HGZ 2010, 162). Meanwhile, as the Cultural Revolution lost momentum in China, some of the young people who had been sent to the countryside in the 1960 s decided to return to urban areas without government endorsement and, therefore, ended up jobless. Some of those living in Nanning, the provincial capital of Guangxi, turned to organizing smuggling rings that imported opium and watches from Vietnam while exporting gold (HGZ 2010, 578).

The Sino-Vietnamese border war of 1979 and its aftermath directly contributed to the bustling smuggling activities on the present-day Sino-Vietnamese border. During the 1970s, the Cold War partnership between Beijing and Hanoi collapsed as China reoriented its foreign policy toward the United States, while Vietnam tilted toward the Soviet Union in the Sino-Soviet split (Khoo 2011). In February 1979, China launched a punitive attack against Vietnam in response to the Vietnamese invasion of Cambodia, which ended the rule of the Chinese-backed Khmer Rouge. While the battle was brief, the war led to a decade-long confrontation between the two former allies along the border characterized by mining and shelling, which had an enormous impact on the lives of the border people (Zhang 2015). The military conflict added new dynamics to smuggling activities at the Sino-Vietnamese border. 
First, the war exacerbated the existing material shortages of the border society, which had provided fertile ground for smuggling. In the late 1970s and early 1980s, most parts of China began to benefit from the economic reforms launched in 1978 that introduced market principles into the planned economy. Agriculture was decollectivized; the country was opened to foreign investment, especially in its coastal areas; and entrepreneurs were permitted to start businesses. On China's border with Vietnam, however, this transformation from political struggle to economic construction was significantly delayed. During the decade-long military confrontation between Beijing and Hanoi, China's border counties were required to "fight while producing." The local societies needed to increase the supply of grains and vegetables to alleviate the food shortages for the military, although shelling and mining during the war had reduced the size of farmland in the border area (Author's personal collection 1979). The war also deindustrialized local societies as factories were moved away from border towns to avoid heavy losses. Therefore, as early as 1980 , with the diminished presence of the military at the border, smuggling resumed on border crossings such as Jingxi - Trà Lĩnh and Dongxin-Móng Cái (HGZ 2010, 162). Realizing that a closed border would only encourage smuggling, Beijing instructed Yunnan and Guangxi provincial governments that it was better not to stop ordinary Vietnamese people coming to the Chinese side for trade. "Instead of letting a spontaneus black market prosper," according to the central government, the border provinces should "capitalize the trend and encourage people to conduct cross-border exchanges in designated places." Following the instruction, several small border markets in less strategically important locations were informally opened to nearby Vietnamese villagers in late 1983 (Fan and Liu 2006, 119-120).

Second, the military confrontation had an ambivalent impact on the tug-of-war between the smugglers and the states. Minefields planted by the Chinese and Vietnamese militaries 
against each other along the border rendered any cross-border activities, including smuggling, extremely dangerous and difficult. From the end of 1975 to 1985, China and Vietnam buttressed their border with more than 100 million landmines, with about 400 minefields along the border. In 1985 alone, seven people in Pingxiang, a border town near the Friendship Pass, were killed and twenty-five wounded by landmines (Nong 2015, 157, 194). With a wartime international boundary protected by the deadly minefields, the two adversaries did not have to rely on regular border patrols.

Even so, as customs houses and legal cross-border exchanges between the two countries were halted due to bilateral hostility, the two communist states had few resources for inspecting, manipulating, and taxing cross-border economic exchanges. After the Sino-Vietnamese border war broke out in February 1979, for instance, both sides evacuated villagers from major battle grounds (SYS 2000, 90). The Vietnamese military destroyed the bridge across the Ka Long River that connected the border stations of the two countries (FCXZ 1993, 58). Before its destruction, people who wanted to travel between Dongxing and Móng Cái were required to use the bridge so that the border police could conduct inspections of their travel documents and baggage. With the route for legal border crossing closed, smuggling across the river was beyond the control of the state. As shelling across the border gradually diminished after 1985, minority groups living along the border were able to carry goods through small mountain paths snaking through the minefields (Womack 1994, 499). However, customs services were not restored until the normalization of Sino-Vietnamese relations in the early 1990s (HGZ 2010, 162). In the late 1980s, therefore, the most serious security concern of the Chinese and Vietnamese states was no longer territorial integrity, but smuggling (Hensengerth 2009).

\section{Smuggling in the Reform Era}


In 1986, Vietnam initiated its economic reform toward the goal of achieving a "socialistoriented market economy" known as Doi Moi, which required a less hostile international environment, especially amid decreasing Soviet aid. In September 1989, Vietnam announced its decision to withdraw from Cambodia. The end of the Vietnamese occupation of Cambodia not only eased Sino-Vietnamese tensions but also paved the way for the normalization of SinoSoviet relations. In November 1991, General Secretary of the Central Committee of the Communist Party of Vietnam Đỗ Mười and Prime Minister Võ Văn Kiệt visited China. In a joint communique resulting from the meeting, the two sides agreed to resolve territorial disputes through negotiation and to settle the issue of immigrants, which symbolized the end of the decade-long hostility between the two previous Cold War partners (Womack 2006).

By 1990, therefore, both the Chinese and Vietnamese border provinces needed to struggle out of the wartime economy to catch up with the tide of market-oriented reform in their countries. On March 20, 1989, the party secretary of the Chinese border town Pingxiang, Gu Shunquan, admitted that

\{ext\}Pingxiang, due to its distinct location, has prioritized preparing for war and supporting the front line for a long time. Because we have invested too much manpower, materials, and funds in war preparation ... our economic construction starts late, suffers a weak foundation, and progresses slowly.... In the meantime, we should shift our focus from muddling war preparation to economic construction as soon as possible. (Nong $2015,194)\{/$ ext $\}$

\{nopara\}Local bureaucrats' desire for economic prosperity, in addition to a slow restoration of border authority after the normalization of Sino-Vietnamese relations, left smugglers with an ideal policy environment in which to continue their profitable business across the border. A 
development-oriented political agenda led the local state to acquiesce and even encourage a transboundary shadow economy (Renmin ribao 2012; China News Service 2015b). The smugglers did not even need to cross the international boundary furtively at night as they had done before to circumvent state inspections.

De-mining efforts by the Chinese and Vietnamese governments further removed the physical obstacles to cross-border economic exchanges, including smuggling. From April 1992 to November 1994, the Chinese military carried out the first round of its de-mining campaign in the mountainous border region in Yunnan province. The second round from December 1997 to March 1999 further cleared some minefields in Yunnan and Guangxi (Yan and Zhang 1999). From 1994 to 2008, the two countries reopened sixty trade routes and twenty-five border markets; the remaining minefields were those more difficult to clear. De-mining efforts at the SinoVietnamese border have carried on to the present. However, although many more minefields are now clear for farming and border crossing, the border institutions in charge of overseeing crossborder connections and extracting revenues have yet to be fully rebuilt. Smuggling thus remains largely unchecked (Renmin ribao 2002).

After 2013, the Chinese government undertook more concerted efforts to crush smuggling on the Ka Long River by increasing the presence of border police along the riverbank. The smugglers, who for generations have navigated the fluctuations in state strength, are exploring new smuggling routes westward in the mountainous border region and eastward in the Beibu Gulf. In 2015, the Guangxi provincial government responded with a proposed project to construct a border fence (China News Service 2015a). The tug-of-war between the state and the smugglers at the Sino-Vietnamese border continues.

\section{Conclusion: The Limits of State Power}


In this article I use smuggling and antismuggling efforts along the Sino-Vietnamese border as a window to explore the layered bilateral relationship between Beijing and Hanoi since the Cold War. During the twentieth century, the relationship between the two countries' highlevel leadership had been vulnerable to both the asymmetric capabilities and attention of the two countries and great power politics (Khoo 2011; Womack 2006). The two sides formed an intense Cold War partnership under the banner of anti-imperialism and anti-Americanism but drifted apart as a result of the Sino-Soviet split and the Sino-US rapprochement. Below this unstable and fitful relationship between the two states, however, exist highly stable and close transnational connections between the Chinese and Vietnamese people. The partnership between the two peoples tends to be most steady in areas beyond the reach of the state, where smuggling and the shadow economy emerge as a vivid example of this reality.

The historical weakness in central government power at the Sino-Vietnamese border made it a paradise for adventurers, marginal social groups, and smugglers. When the Chinese and Vietnamese communists came to power, smugglers became the enemies of the centralized command economy and the targets of suppression. However, even in the era of high socialism, transnational smuggling networks still survived government crackdowns because while the international socialist movement led to a Sino-Vietnamese partnership it also resulted in material shortages in both countries. As the two countries headed toward a decade-long border collision, the resources of local administrations were further diverted from crushing the flourishing shadow economy. Cross-border smuggling networks, therefore, were part of a rather stable transnational partnership between the two peoples that survived despite a highly volatile political relationship between the two countries. 
The resilient smuggling networks along the Sino-Vietnamese border during the Cold War provide important lessons to current antismuggling campaigns in the area. While state weakness at the border created a favorable policy environment for smugglers, simply imposing more coercive measures does not suffice to crush smuggling. The roots of illicit economic activities at the Sino-Vietnamese border lie in China's large domestic demand, be it for precious metals during wartime, staple foods during periods of famine, or high-end products after China's economic takeoff. If the Chinese government does not further open the domestic market to imported goods in order to accommodate the new consumption demands of China's middle class, foreign products will continue to flow into the country in the form of contraband items, and Vietnam will remain an important relay station for smuggling activities. For border towns such as Dongxing and Pingxiang, their role as transportation hubs for smuggling activities remains core to their economic well-being. Helping the border population find alternative livelihoods, therefore, should be a substantial part of the antismuggling campaign.

The historical and present situations discussed in this article raise further questions for studies of China's relations with its Asian neighbors during the Cold War. First, under the overarching theme of Cold War ideological conflicts, how did those undercurrents that moved beyond the control of the centralized state shape China's relations with its neighboring countries? Second, aside from the issue of territorial disputes, how has overcoming state weakness affected the border areas between China and its Asian neighbors, and how might it do so in the future?

\section{Notes}

Qingfei Yin is assistant professor of world and Chinese history at the Virginia Military Institute. She can be reached at yinq@vmi.edu.

Research for this paper was funded by George Washington University, the Henry Luce Foundation/American Council of Learned Societies Program in China Studies, and the Association for Asian Studies China and Inner Asia Council. 


\section{References}

Author's personal collection. Various Years.

Boel, Bent. 2014. "Bible Smuggling and Human Rights in the Cold War." In Luc van Dongen, Stéphanie Roulin, and Giles Scott-Smith, eds., Transnational Anti-Communism and the Cold War: Agents, Activities, and Networks. London: Palgrave Macmillan, pp. 263-275.

Bren, Paulina, and Mary Neuburger. 2012. Communism Unwrapped: Consumption in Cold War Eastern Europe. Oxford: Oxford University Press.

Chan, Anita, and Jonathan Unger. 1982. "Grey and Black: The Hidden Economy of Rural China." Pacific Affairs, vol. 55, no. 3 (October), pp. 452-471.

Chen, Fan. 1944. "Dongxing: Xinde Guangzhouwan” [Dongxing: The new Kwangchou Wan]. Lvxing zazhi [China traveler], vol. 18, no. 8, pp. 61-64.

Chen, King C. 1969. Vietnam and China, 1938-1954. Princeton: Princeton University Press.

China Daily. 2017. “Gong'anbu: Zhong-Yue jiaqiang zhifa hezuo, daji kuaguo guaimai fanzui” [Ministry of Public Security: China and Vietnam strengthen collaboration in law enforcement to strike cross-border human trafficking], May 22.

China News Service. 2015a. "Guangxi jiangzai Zhong-Yue bianjing jian 8gongli weilan zhuangbei jiankong sheshi" [Guangxi will construct an eight-mile fence with surveillance equipment along the Sino-Vietnamese border], April 29.

- 2015b. "Guangxi 3ming haiguan guanyuan fangzong zousi shouhui 320wan bei qisu" [Three Guangxi Customs officials persecuted for letting smuggling unchecked and taking bribery of 3.2 million], December 4.

Decoux, Jean. 1949. A la barre de l'Indochine: Histoire de mon Gouvernement Général, 19401945. Paris: Plon.

Dikötter, Frank. 2017. The Cultural Revolution: A People's History, 1962-1976. New York: Bloomsbury Press.

Fan, Honggui, and Zhiqiang Liu. 2006. Zhong-Yue bianjing maoyi yanjiu [A study on ChinaVietnam border trade]. Beijing: Minzu chubanshe.

FCXZ (Fangcheng xianzhi [Gazetteer of Fangcheng county]). 1993. http://lib.gxdfz.org.cn/viewc58-2.html (accessed May 10, 2018). 
GDPA (Guangdong Provincial Archives). Various years. Guangdong, China.

Grémont, Johann. 2017. "Pirates et contrebandiers le long de la frontière sino-vietnamienne: Une frontière à l'épreuve (1895-1940)?" PhD diss., University of Paris-Diderot.

Grossman, Gregory. 1977. "The Second Economy of the USSR." Problems of Communism, vol. 26, no. 40 (September-October), pp. 25-40.

GSBN. 2006. Zhonghua renmin gonghe guoshi biannian: 1950 nianjuan [Chronological history of the People's Republic of China, 1950]. Beijing: Dangdai Zhongguo chubanshe.

Guangxi ribao [Guangxi daily]. 1952. "'Faguo shoubiao' de zui'e” [The evil 'French watches'], February 25.

Guo, Ming. 1992. Zhong-Yue guanxi yanbian sishinian [The forty-year evolution of SinoVietnamese relations]. Nanning: Guangxi renmin chubanshe.

GXZG (Guangxisheng Zhengfu Gongbao [Bulletin of Guangxi provincial government]). 1941. Guangxi, China.

GZARA (Guangxi Zhuang Autonomous Region Archives). Various years. Nanning, Guangxi.

Hensengerth, Oliver. 2009. Regionalism in China-Vietnam Relations: Institution-Building in the Greater Mekong Subregion. New York: Routledge.

HGZ (Guangxi tongzhi: Haiguanzhi [Gazatteer of Guangxi customs]). 2010. http://lib.gxdfz.org.cn/view-a50-1.html (accessed May 10, 2018).

HGZK (Huguang zhoukan [The light of Shanghai weekly]). 1949. "Wanglai Gui-Yue bianjing shenmi de yiqun!" [A mysterious group along the Guangxi-Vietnam border], no. 2.

Khoo, Nicholas. 2011. Collateral Damage: Sino-Soviet Rivalry and the Termination of the SinoVietnamese Alliance. New York: Columbia University Press.

Lary, Diana. 2007. "A Zone of Nebulous Menace: The Guangxi/Indochina Border in the Republican Period." In Diana Lary, ed., The Chinese State at the Borders. Vancouver: University of British Columbia Press, pp. 181-197.

Lessard, Micheline. 2015. Human Trafficking in Colonial Vietnam. London: Routledge.

Ministry of Finance of the Democratic Republic of Vietnam. 1964. "Thông tư 140-TC-TQD-T năm 1964 bổ sung Thông tư 802-TC-TQD năm 1962 về việc trả thù lao cho những người tham gia bắt lậu do Bộ Tài chính ban hành" [Circular 140-TC-TQD-T of 1964 supplementing Circular 802-TC-TQD of 1962 on the payment of remuneration to participants of antismuggling]. https://thukyluat.vn/vb/thong-tu-140-tc-tqd-t-nam-1964-bo- 
sung-thong-tu-802-tc-tqd-nam-1962-ve-viec-tra-thu-lao-cho-nhung-nguoi-tham-gia-batlau-do-bo-tai-chinh-ban-hanh-4cc9.html (accessed May 26, 2017).

NADRV (National Assembly of the Democratic Republic of Vietnam). 1959. "Nghị quyết về việc tiến hành hợp tác hóa nông nghiệp kết hợp hoàn thành cải cách dân chủ miền núi do Hội đồng Chính phủ ban hành [Resolution on the implementation of agricultural cooperation in combination with the completion of democratic reform in the mountainous area promulgated by the Council of Ministers]. https://thukyluat.vn/vb/nghi-quyet-ve-viectien-hanh-hop-tac-hoa-nong-nghiep-ket-hop-hoan-thanh-cai-cach-dan-chu-mien-nui-dohoi-dong-chinh-phu-ban-hanh-5adc.html (accessed July 17, 2017).

Nanfang zhoumo [Southern daily]. 2014. "Meinian 200 wandun zousirou xingxiao bianji quanguo: dangbuzhu de zousirou" [Two million tons of smuggled meat sold nationwide each year: unstoppable smuggled meat], December 15.

Nguyen, Lien-Hang T. 2012. Hanoi's War: An International History of the War for Peace in Vietnam. Chapel Hill: University of North Carolina Press.

Nong, Wenke. 2015. Zhongguo gongchandang Pingxiang lishi di 2 juan (1949-1991) [History of the CCP in Pingxiang (1949-1991)]. Nanning: Guangxi renmin chubanshe.

Notice sur le Kouang-Si rédigée à l'Etat-major des troupes de l'Indo-Chine (mars 1900). 1900. Hanoi: F.-H. Schneider.

Renmin ribao [People's daily]. 2002. "Kanjie libei qingzhang'ai, Zhong-Yue bianjing zai pailei" [De-mining campaign start again in China-Vietnam border for the purpose of boundary settlement and demarcation], October 21 .

- 2012. "Guangxi yanda bianjing zousi" [Guangxi strikes harshly on cross-border smuggling], June 13.

Scott, James C. 2009. The Art of Not Being Governed: An Anarchist History of Upland Southeast Asia. New Haven: Yale University Press.

Sieg, Kent, ed. 2002. Foreign Relations of the United States, 1964-1968, vol. 5: Vietnam 1967. Washington, DC: US Government Printing Office.

Sutton, Donald S. 1995. "Consuming Counterrevolution: The Ritual and Culture of Cannibalism in Wuxian, Guangxi, China, May to July 1968." Comparative Studies in Society and History, vol. 37, no. 1, pp. 136-172. 
SYS (Guangxi tongzhi: Shangyezhi [Gazatteer of commerce in Guangxi]). 2000. http://lib.gxdfz.org.cn/view-a78-90.html (accessed June 30, 2018).

Tagliacozzo, Eric. 2005. Secret Trades, Porous Borders: Smuggling and States Along a Southeast Asian Frontier, 1865-1915. New Haven: Yale University Press.

Thai, Philip. 2016. "Law, Sovereignty, and the War on Smuggling in Coastal China, 1928-1937." Law and History Review, vol. 34, no. 1, pp. 75-114.

- 2017. "Old Menace in New China: Coastal Smuggling, Illicit Markets, and Symbiotic Economies in the Early People's Republic." Modern Asian Studies, vol. 51, no. 5, pp. 1561-1597.

Turner, Sarah. 2010. "Borderlands and Border Narratives: A Longitudinal Study of Challenges and Opportunities for Local Traders Shaped by the Sino-Vietnamese Border." Journal of Global History, vol. 5, no. 2, pp. 265-287.

Turner, Sarah, Christine Bonnin, and Jean Michaud. 2015. Frontier Livelihoods: Hmong in the Sino-Vietnamese Borderlands. Seattle: University of Washington Press.

VNA PTT (Vietnamese National Archives, Phủ Thủ tướng [Prime Minister's Office]). Various years. Collection 3. Trung tâm Lưu trữ Quốc gia, Center III. Hanoi, Vietnam.

VNA UHKVB (Vietnamese National Archives, Ủy ban Hành chính Khu tự trị Việt Bắc [Administrative Committee of Northern Vietnam Autonomous Region]). 1948-1976. Trung tâm Lưu trữ Quốc gia, Center III. Hanoi, Vietnam.

Westad, Odd Arne. 2012. "The Cold War and the International History of the Twentieth Century." In Melvyn P. Leffler and Odd Arne Westad, eds., The Cambridge History of the Cold War, vol. 1: Origins. Cambridge: Cambridge University Press, pp. 1-19.

Womack, Brantly. 1994. "Sino-Vietnamese Border Trade: The Edge of Normalization." Asian Survey, vol. 35, no. 6, pp. 495-512.

- 2000. "International Relationships at the Border of China and Vietnam: An Introduction." Asian Survey, vol. 40, no. 6, pp. 981-986.

- 2006. China and Vietnam: The Politics of Asymmetry. Cambridge: Cambridge University Press.

Woodside, Alexander. 1971. Vietnam and the Chinese Model: A Comparative Study of Vietnamese and Chinese Government in the First Half of the Nineteenth Century. Cambridge: Harvard University Asia Center. 
Xinhua Net. 2017. 'Zhong-Yue 'liangguo sifang' haiguan qidong daji kuajing zousi lianhe xingdong" [Customs of four border provinces of China and Vietnam launch joint antismuggling campaign], November 28.

Yan, Xiaoping, and Zhang Rui. 1999. "Zhong-Yue bianjing dasaolei de jingyan jiqi qishi" [Experience and implications of de-mining efforts at the Sino-Vietnamese border]. Junshi lishi [Military history], no. 6, pp. 17-20.

Zeng, Fusheng. 1993. Youyiguan bianfang jianchazhan zhanzhi [Gazetteer of the border check station of Friendship Pass]. Nanning: Youyiguan bianfang jianchazhan zhanzhi bianweihui.

Zhai, Qiang. 2000. China and the Vietnam Wars, 1950-1975. Chapel Hill: University of North Carolina Press.

Zhang, Xiaoming. 2015. Deng Xiaoping's Long War: The Military Conflict Between China and Vietnam. Chapel Hill: University of North Carolina Press. 